\title{
THE FLOWERING, POLLEN PRODUCTION, AND INSECT VISITORS IN THE ORNAMENTAL SHRUB POTENTILLA FRUTICOSA L. (ROSACEAE)
}

\author{
Bożena Denisow ${ }^{*}$, Sebastian Antoń ${ }^{1}$, Grażya Szymczak ${ }^{2}$ \\ 'Department of Botany, University of Life Sciences in Lublin, \\ 15 Akademicka Str, 20-950 Lublin, Poland \\ ${ }^{2}$ Botanical Garden, Maria Curie-Skłodowska University, \\ 3 Sławinkowska Str., 20-810 Lublin, Poland \\ *corresponding author: bozena.denisow@up.lublin.pl
}

Received 7 February 2013; accepted 14 May 2013

$\mathrm{S} \mathrm{u} \mathrm{m} \mathrm{m} \mathrm{a} \mathrm{r} \mathrm{y}$

Urban areas have a specific ecological environment and may help to sustain local pollinator populations by the cultivation of different ornamental plants with entomophilous flowers. This yearlong study examined the flowering pattern, abundance of flowering, pollen production as well as insect visitation of two cultivars of the ornamental shrub Potentilla fruticosa L. ('Maanleys' and 'Blink'), grown in Lublin; a city in south-eastern Poland. P. fruticosa 'Maanleys' bloomed from the middle of May to the first decade of September and P. fruticosa 'Blink' from June until October. The pattern of diurnal flowering was similar for both cultivars and showed plasticity in the season. Flowers opened most intensively in the morning hours, and $80-90 \%$ of the daily installment of newly opened flowers expanded by $8.00 \mathrm{~h} \mathrm{GMT}+2 \mathrm{~h}$. A delay in the peak of diurnal flowering was noted between the spring/summer and summer/autumn periods. The most intense blooming fell in the $2^{\text {nd }}$ month of flowering. The mass of pollen produced per flower depended on both the number of anthers and the efficiency of archesporial tissues. The pollen output varied from 1.4 to $7.2 \mathrm{mg}$ per 10 flowers ('Maanleys') and from 2.6 to $4.5 \mathrm{mg}$ per 10 flowers ('Blink'). The mass of pollen produced per individual shrub was substantially related to the abundance of blooming. The average estimated pollen productivity in the full flowering phase was low; $1 \mathrm{~g}$ ('Maanleys') and $1.5 \mathrm{~g}$ ('Blink') per $10 \mathrm{~m}^{2}$ of shrub crown. The flowers of Potentilla fruticosa attracted numerous insects, mainly solitary bees (33 - 43\%), dipterans (31-42\%), lepidopterans (4 - 14\%), bumblebees (3-15\%), and honey bees (3 - 4\%). The Potentilla fruticosa 'Maanleys' and 'Blink' are propagated for specific ornamental arrangements and due to a long flowering period may be used in small urban courtyards for both decorative value and as a pollen delivering plants.

Keywords: diurnal pattern of blooming, pollen yield, pollinators conservation, bee pastures, Potentilla fruticosa $\mathrm{L}$.

\section{INTRODUCTION}

Bees and other insect flower visitors need a continuous food supply throughout their whole life cycle. Pollen and nectar provide the complete diet for both the adults and their larvae. Nowadays, all kinds of bees are threatened, mainly because their nesting sites and food plants are frequently destroyed by human activity (Williams et al., 1991; Torchio, 1994; Banaszak, 1995). This has resulted in a decrease in bee populations in many parts of the world (e.g. Goulson et al., 2008). The first step to encourage bees is to support general plant biodiversity (Fussell and Corbet, 1992; Banaszak, 1995; Aizen et al., 2002; Denisow 2009; 2011).

Until the early 1990s, agricultural areas received the most interest when it came to bee pasture improvement, while urban areas have a great potential for pollinator recovery (Fussell and Corbet, 1992; Masierowska, 2012). For a long time, 
different ornamentals, i.e. shrubs, have been reported as a source of nectar and pollen flow (Szklanowska, 1983; Szklanowska and Strzałkowska, 2001; Kołtowski, 2006; Lipiński, 2010; Wróblewska and Stawiarz, 2012).

The investigations of plant species as food for pollinators are important. Include in the investigations are flowering phenology, nectar secretion, and pollen production (Goulson, 1999; van Overbeke et al., 2007; Hedhly et al., 2008). The period, duration of blooming, and abundance of flowering are essential when choosing species for bee pastures (Robertson and Macnair, 1995; van Doorn and van Meeteren, 2003). The total pollen and nectar yield are decisive in the control of the food supply (Kołtowski and Jabłoński, 2001). Moreover, different specific features of flower morphology and floral rewards have an impact on the attractiveness for insect visitors (Keijzer, 1987; Faegri and van der Pij1, 1979; Carreck and Williams, 1997; reviewed by Goulson, 1999).

The genus Potentilla, in the Rosaceae family, includes over 300 species with a variability of life forms (annual, biennial, and perennial). Potentilla fruticosa $\mathrm{L}$. is a deciduous shrub native to the northern hemisphere. It is often found growing at high altitudes in mountains and performs well in moderate subcontinental climates (Guillen et al., 2005). The shrubs are dense with numerous upright branches which form buttercup flowers. These shrubs are often grown as ornamentals in different kinds of arrangements. Some Rosaceae species are known as food plants for wild bees (Teper, 2005). Potentilla fruticosa L. - a decidous shrub, is native to North America and in the wild, they have yellow flowers. The flowers of horticultural cultivars are white, yellow ('Maanleys'), pink ('Blink'), orange or red. Inflorescences are terminal and appear in clusters. Flowers are hermaphroditic, actinomorphic, and disk-shaped (Bugała, 2000).
The main objective of the long-term study was 1) to examine the floral phenology and diurnal dynamics of flowering for two ornamental cultivars of Potentilla fruticosa 'Maanleys' and 'Blink', 2) to estimate the quantity of pollen that can serve as food for insects, and 3) to monitor the activity and spectrum of insect visitors.

\section{MATERIAL AND METHODS}

\section{Study sites and study species}

The observations were conducted in long-term sequence studies in 2001-2002, 2005, 2008, and 2012 in the Lublin area, Poland. The shrubs of two cultivars of Potentilla fruticosa: 'Maanleys' and 'Blink', were grown in different parts of the city. The cultivar 'Maanleys' was grown at the arboretum in the Botanical Garden of Maria Curie-Skłodowska University (ATPOL - FE2765) and in a private garden in the district of Sławin (ATPOL - FE2773). The cultivar 'Blink' was grown only in a private garden in the district of Sławin (ATPOL FE2773). On both sites, shrubs were grown on a loess originated soil.

\section{Flowering observations}

During the growing seasons, detailed observations of the flowering biology were conducted. The onset and length of the blooming period was recorded. The observations of the diurnal model of blooming were made in 2008 and 2012 on the individuals grown on the Sławin district site. Protocols described by Jabłoński and Szklanow ska (1997), and Denisow (2009) were applied. The duration of the successive phases of blooming (beginning, full, terminal) were recorded. The onset of flowering was determined according to an assumption that the beginning of the blooming period was the moment when $10 \%$ of the flowers had bloomed, the full blooming period was assumed to be when $70-80 \%$ of the flowers were in bloom, the termination of blooming was assumed to be when over $85 \%$ of the flowers had finished blooming.

The diurnal pattern of flowering was expressed as the percentage of newly opened flowers in relation to the total 
number of flowers opened during the day. Due to the long period of blooming, these observations were made in full spring (June) and in full summer (August) for three consecutive days, for each period. The development of flowers was noted in one-hour intervals (GMT $+2 h$ ). To determine flower life-span, the buds $(\mathrm{n}=10$ per each cultivar) were randomly chosen on different individual shrubs. The buds were marked just before opening and their development was observed. The flower life-span was defined as the period from bud-opening until the falling of petals.

The average number of flowers produced per each individual shrub was established for the initial, full, and terminal phases of flowering. The abundance of blooming was determined on the basis of random circular areas $0.1 \mathrm{~m}^{2}$ (36.7 $\mathrm{cm}$ in diameter). The data were converted to the number of flowers per $1 \mathrm{~m}^{2}$ of shrub crown. The counts were made separately for each station and were used to estimate the total pollen production.

Pollen production was assayed using the method of Szklanowska (1995). The mass of pollen was determined in the full blooming phase. Mature but unopened anthers $(n=100)$ were collected in weighed glass containers in four replications. Subsequently, the glass containers with anthers were placed into a dryer (ELCON CL 65) at ca. $33^{\circ} \mathrm{C}$. The pollen was rinsed from the anthers once with pure ether $(1-2 \mathrm{ml})$, and then 4 - 6 times with $70 \%$ ethanol $(2-8 \mathrm{ml})$. The accuracy of the pollen rinsing was checked using a binocular. The mass of produced pollen was calculated for 100 anthers, 10 flowers, and per $1 \mathrm{~m}^{2}$ of the shrub crown area. Pollen viability was tested in standard acetocarmine slides. We checked the secretion of nectar in 2012 by bagging flowers with tulle isolators and applying the pipette method (Jabłoński, 2002).

\section{Insect activity}

The blooming observations and the pattern and intensity of insect visits were both noted at the same time. The daily pattern of insect visitation for the full flowering period was recorded in 2008 and 2012 for the individual shrubs grown in the district of Sławin. The visitation observations were made for three consecutive days at one-hour intervals, at the time of the most intensive forage activity of pollinators, between 6.00 and $20.00 \mathrm{~h}(\mathrm{GMT}+2.00 \mathrm{~h})$. During each observation census, the total number of visiting insects was recorded. The following categories were determined: 1. Apis mellifera, 2. Bombus species, 3. other Apoidea (solitary bees), 4. Diptera, 5. Lepidoptera, and 6. Coleoptera.

The meteorological factors during the growing season of 2001 were comparable to the long term means. In 2002, it was relatively warm $(110.6 \%$ of normal air temperature) with total precipitation $(456.7 \mathrm{~mm})$ lower than the long-term mean $(520.1 \mathrm{~mm})$. The mean precipitation for June-August was $23.2 \mathrm{~mm}$, and was approx. $70 \%$ lower compared to the long-term (mean $=77.2$ for JuneAugust). In May of 2005 rainfall (mean $=96 \mathrm{~mm}$ ), exceeded the normal level (ca. 65\%). Intensive rainfall events were recorded in July (mean $=109.0 \mathrm{~mm}$ ), and August (mean $=108.7 \mathrm{~mm}$ ), with total rainfall approx. $40 \%$ and $50 \%$ above normal, respectively. In May of 2008 the precipitation $($ mean $=101.6)$ was approx. $50 \%$ higher than the long-term data. The summer was extremely dry with June rainfall $($ mean $=77.1)$ ca. $65 \%$ lower compared to the long-term data. In the summer of 2012, the precipitation was approx. $30 \%$ lower than that shown in the long-term data.

The weather station located in Felin in the Lublin Upland, provided the weather data. Monthly and decade means of the air temperature and precipitation were compared to the long-term data of 19512005.

\section{Data analysis}

Data are presented as means with SD. The standard analysis of variance was applied (Stanisz, 1996). Post hoc comparison of means was tested by the HSD Tukey test. The level of statistical significance for all analyses was at $\alpha=0.05$. All analyses were performed using Statistica ver. 6.0 (StatSoft Poland, Krakow). 


\section{RESULTS}

The detailed dates of seasonal phenology are shown in Table 1. During the study period, Potentilla fruticosa 'Maanleys' bloomed three to six weeks earlier than 'Blink'. The flowering began in mid-May ('Maanleys') or in June/July ('Blink') and lasted till mid-August or mid-September ('Maanleys') and till October ('Blink'). The duration of flowering varied from 70 - 120 days ('Maanleys') and from 90 - 100 days ('Blink'). The flowers opened almost simultaneously in both cultivars, but a delay in the peak of flowering was noted between the spring/summer and summer/autumn periods. In June, the flowers opened as early as $5.00 \mathrm{~h}$ with peak at 6.00 for 'Maanleys' (Fig. 1) and at 7.00 for 'Blink' (Fig. 2). On average, $90 \%$ of daily installment of newly opened flowers expanded by $8.00 \mathrm{~h}(\mathrm{GMT}+2 \mathrm{~h})$. In August, the flower opening started an hour later - at 6.00 , with a peak at 7.00 for
'Maanleys', and between 7.00 - 8.00 for 'Blink'.

The flowers of Potentilla fruticosa 'Maanleys' and 'Blink' have pale yellow and bright pink corolla, respectively. The flowers of both cultivars are hermaphrodite, have a centrally positioned gynoecium of 12 - 40 pistils, and have spirally arranged multi-anthers androecium (Fig. 3A). The base of the ovary is covered with numerous multicellular hairs (Fig. 3B).

Thelife-span ofasingle 'Maanleys' flower was $4-11$ days (mean $=5.3 \pm 1.2 \mathrm{SD})$ and 3 - 5 days (mean $=4.4 \pm 0.7 \mathrm{SD})$ of a single 'Blink' flower. New flowers constantly developed on each individual shrub. The number of flowers per shrub was cultivar related (Tab. 1). The number of flowers in bloom of an individual shrub differed significantly among blooming phases. Year-to-year variations were also found. In the initial phase of flowering, 21.2 flowers per $1 \mathrm{~m}^{2}$ were in bloom on the 'Maanleys'

Table 1 .

The phenology and abundance of flowering of Potentilla fruticosa cv. 'Maanleys' and 'Blink' in the years of study in the Lublin area, Poland;

mean values, standard deviation (SD) and coefficient of variation (V) are given

\begin{tabular}{|c|c|c|c|c|c|c|}
\hline \multirow{4}{*}{ Cultivar } & \multirow{4}{*}{ Year } & \multirow{4}{*}{$\begin{array}{l}\text { Flowering } \\
\text { period }\end{array}$} & \multirow{4}{*}{$\begin{array}{l}\text { Flowering } \\
\text { length } \\
\text { (days) }\end{array}$} & \multicolumn{3}{|c|}{ Number of flowers per $1 \mathrm{~m}^{2}$ of crown } \\
\hline & & & & \multicolumn{3}{|c|}{ flowering phase } \\
\hline & & & & beginning & full & end \\
\hline & & & & $\begin{array}{c}\text { Mean } \pm \text { SD } \\
\text { V\% }\end{array}$ & $\begin{array}{c}\text { Mean } \pm \text { SD } \\
\text { V\% }\end{array}$ & $\begin{array}{c}\text { Mean } \pm \text { SD } \\
\text { V\% }\end{array}$ \\
\hline \multirow{6}{*}{$\begin{array}{l}\text { Potentilla } \\
\text { fruticosa } \\
\text { 'Maanleys' }\end{array}$} & 2001 & $18.05-08.09$ & 112 & $\begin{array}{c}26.7 \pm 13.9 \\
52.1 \%\end{array}$ & $\begin{array}{c}62.2 \pm 24.8 \\
39.9 \%\end{array}$ & $\begin{array}{c}31.8 \pm 16.9 \\
53.1 \%\end{array}$ \\
\hline & 2002 & $2.06-09.08$ & 69 & $\begin{array}{c}34.0 \pm 13.5 \\
39.7 \%\end{array}$ & $\begin{array}{c}210.4 \pm 184.1 \\
87.5 \% \\
\end{array}$ & $\begin{array}{c}31.7 \pm 14.7 \\
46.4 \% \\
\end{array}$ \\
\hline & 2005 & $20.05-20.09$ & 120 & $\begin{array}{c}37.0 \pm 19.8 \\
53.5 \%\end{array}$ & $\begin{array}{c}165.0 \pm 56.0 \\
33.9 \%\end{array}$ & $\begin{array}{c}56.4 \pm 17.0 \\
30.1 \% \\
\end{array}$ \\
\hline & 2008 & $15.05-6.09$ & 106 & $\begin{array}{c}34.0 \pm 16.0 \\
47.1 \%\end{array}$ & $\begin{array}{c}571.0 \pm 205.1 \\
35.9 \%\end{array}$ & $\begin{array}{c}76.8 \pm 17.2 \\
22.4 \% \\
\end{array}$ \\
\hline & 2012 & $11.05-3.09$ & 110 & $\begin{array}{l}8.4 \pm 2.1 \\
25.0 \% \\
\end{array}$ & $\begin{array}{c}235.5 \pm 78.6 \\
33.4 \% \\
\end{array}$ & $\begin{array}{c}56.6 \pm 18.8 \\
33.2 \% \\
\end{array}$ \\
\hline & Mean & & 103.4 & $\begin{array}{c}21.2 \pm 11.2 \\
52.8 \%\end{array}$ & $\begin{array}{c}248.8 \pm 104.6 \\
42.0 \%\end{array}$ & $\begin{array}{c}50.7 \pm 15.3 \\
30.2 \%\end{array}$ \\
\hline \multirow{4}{*}{$\begin{array}{l}\text { Potentilla } \\
\text { fruticosa } \\
\text { 'Blink' }\end{array}$} & 2005 & $20.06-21.09$ & 91 & $\begin{array}{c}58.8 \pm 28.9 \\
49.1 \%\end{array}$ & $\begin{array}{c}412.5 \pm 201.6 \\
48.9 \%\end{array}$ & $\begin{array}{c}27.8 \pm 30.6 \\
110.0 \% \\
\end{array}$ \\
\hline & 2008 & $8.06-01.10$ & 102 & $\begin{array}{c}57.5 \pm 14.2 \\
24.7 \% \\
\end{array}$ & $\begin{array}{c}402.5 \pm 345.9 \\
85.9 \% \\
\end{array}$ & $\begin{array}{c}18.5 \pm 14.4 \\
77.8 \% \\
\end{array}$ \\
\hline & 2012 & $1.07-10.10$ & 101 & $\begin{array}{c}73.4 \pm 23.3 \\
31.7 \%\end{array}$ & $\begin{array}{c}325.0 \pm 134.2 \\
41.3 \% \\
\end{array}$ & $\begin{array}{c}81.7 \pm 43.1 \\
52.8 \% \\
\end{array}$ \\
\hline & Mean & & 98.0 & $\begin{array}{c}63.2 \pm 18.6 \\
29.4 \% \\
\end{array}$ & $\begin{array}{c}380 \pm 185.1 \\
48.7 \% \\
\end{array}$ & $\begin{array}{c}42.7 \pm 21.8 \\
51.1 \% \\
\end{array}$ \\
\hline
\end{tabular}




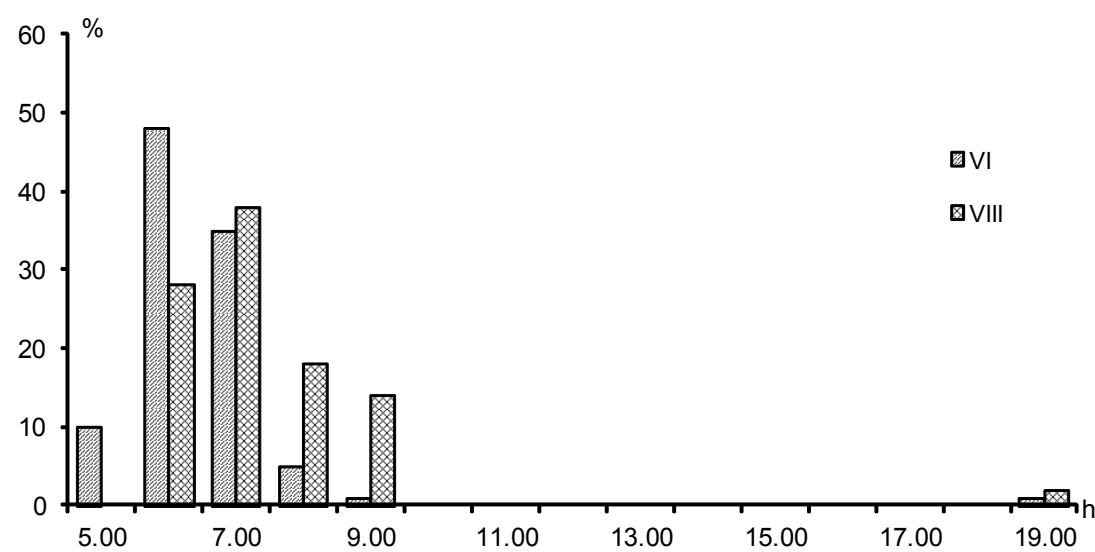

Fig. 1. The proportion of flowers developed in 1-hour intervals on Potentilla fruticosa 'Maanleys' studied during June and August in Lublin, SE Poland. Mean from 2008 and 2012.

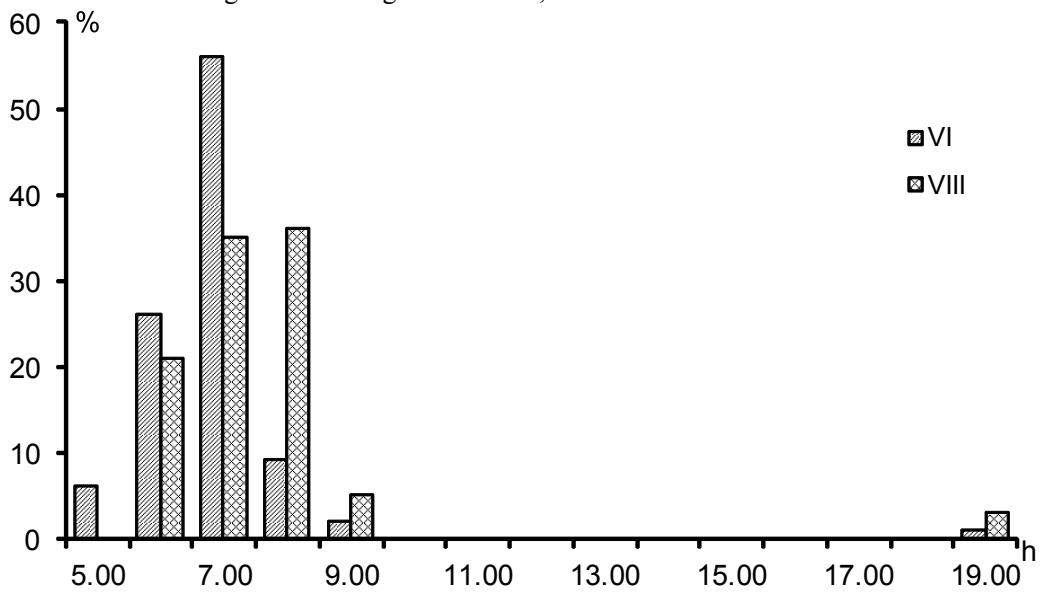

Fig. 2. The proportion of flowers developed in 1-hour intervals on Potentilla fruticosa 'Blink' studied during June and August in Lublin, SE Poland. Mean from 2008 and 2012.
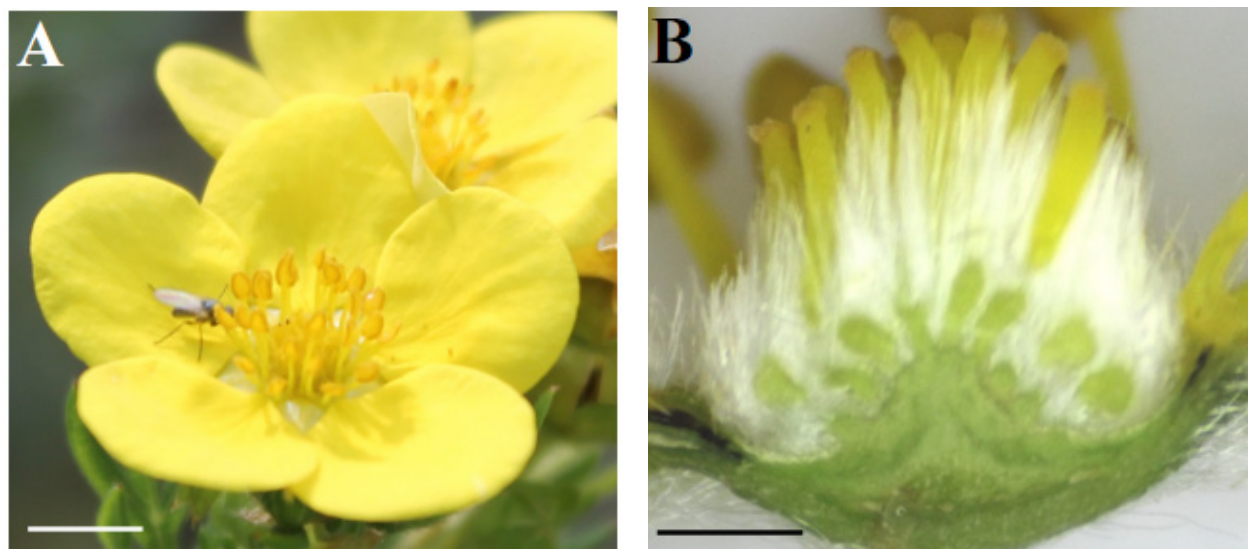

Fig. 3. Habit of the flower of Potentilla fruticosa 'Maanleys' at anthesis, macro photographs.

(A) pale yellow flowers, note Diptera collecting pollen. Scale bar $=1 \mathrm{~cm}$.

(B) hairs at the base of the ovary that reflect sunlight and mimic nectar droplets. Scale bar $=1 \mathrm{~mm}$. 
shrubs and 63.2 per $1 \mathrm{~m}^{2}$ on the 'Blink' shrubs and the blooming was more stable $(\mathrm{V} \%=29.4$ 'Blink' vs. 52.8 'Maanleys'). Similarly, during the full flowering phase, the 'Blink' shrubs bloomed more abundantly $\left(\right.$ mean $=380.0$ per $1 \mathrm{~m}^{2}$ vs. mean $=248.8$ 'Maanleys').

The release of pollen began approx. 4 - 5 hours after the corolla opened. Most anthers dehisced between 12.00 and 14.00 $(\mathrm{GMT}+2 \mathrm{~h})$. Usually pollen was released simultaneously in $5-10$ anthers per single flower. At a mean air temperature of $25-30{ }^{\circ} \mathrm{C}$, the pollen release was very intensive. The entire quantity of pollen per anther was released in $2-3$ hours. During temperature drops, where the mean was $15-20{ }^{\circ} \mathrm{C}$, the process was slower and lasted $5-8$ hours. The anthers open gradually from outward to inward.

The number of anthers per flower depended on the cultivar $(\mathrm{df}=1, \mathrm{~F}=36.13$, $\mathrm{p}<0.001)$. Year-to-year variations were found $(\mathrm{df}=4, \mathrm{~F}=14.89, \mathrm{p}<0.001)$. A significantly higher mean number of anthers was recorded for $P$. fruticosa 'Blink' (mean = 31.1) vs. 'Maanleys' $($ mean $=25.4)($ Tab. 2) .

The statistical analysis of the mass of pollen produced in anthers showed a significant year effect, for $P$. fruticosa 'Maanleys' $(\mathrm{p}=0.014, \mathrm{df}=2)$ and P. fruticosa 'Blink' $(\mathrm{p}=0.033, \mathrm{df}=4)$.
Extremely low amounts were produced in 2002 ('Maanleys') and 2008 ('Blink'). No cultivar effect was found for the mass of pollen produced. A negative correlation between the mass of pollen produced in the anthers and the number of anthers per flower was found $(r=-0.215)$. The lowest mass of pollen produced by $P$. fruticosa 'Maanleys' was characteristic for 2002 (mean $=0.5 \mathrm{mg}$ per 100 anthers), and the highest for 2001 and 2005 (mean $=2.3 \mathrm{mg}$ and $2.8 \mathrm{mg}$ per 100 anthers, respectively). A negative correlation between the mass of pollen per 100 anthers and air temperature was found $(\mathrm{r}=-0.122)$. A positive correlation was found between the mass of pollen per 100 anthers and precipitation $(r=0.434)$.

The mass of pollen produced per flower depended on both the number of anthers and the efficiency of the archesporial tissues. The average pollen output was from 1.4 to $7.2 \mathrm{mg}$ per 10 flowers ('Maanleys') and from 2.6 to $4.5 \mathrm{mg}$ per 10 flowers ('Blink'). The mass of pollen produced per individual shrub was substantially related to the abundance of blooming. The average estimated pollen productivity in the full flowering phase was low $1 \mathrm{~g}$ ('Maanleys') and $1.5 \mathrm{~g}$ ('Blink') per $10 \mathrm{~m}^{2}$ of shrub crown (Fig. 4).

The characteristic of androecium and the mass of pollen produced in anthers and flowers of Potentilla fruticosa cv. 'Maanleys' and 'Blink' in the years of study in the Lublin area, Poland; mean values, standard deviation (SD) and coefficient of variation (V) are given

\begin{tabular}{|c|c|c|c|c|c|c|c|c|}
\hline \multirow{2}{*}{ Cultivar } & \multirow{2}{*}{ Year } & \multicolumn{3}{|c|}{$\begin{array}{c}\text { Number of anthers } \\
\text { per flower }\end{array}$} & \multicolumn{3}{|c|}{$\begin{array}{c}\text { Mass of pollen } \\
\text { per } 100 \text { anthers }(\mathrm{mg})\end{array}$} & \multirow{2}{*}{$\begin{array}{c}\text { Mass of pollen per } \\
10 \text { flowers }(\mathrm{mg}) \\
\text { mean }\end{array}$} \\
\hline & & $\min -\max$ & $\begin{array}{c}\text { mean } \\
\pm S D\end{array}$ & V\% & $\min -\max$ & $\begin{array}{l}\text { mean } \\
\pm S D\end{array}$ & V\% & \\
\hline \multirow{6}{*}{$\begin{array}{l}\text { Potentilla } \\
\text { fruticosa } \\
\text { 'Maanleys' }\end{array}$} & 2001 & $19-27$ & $21.6_{a} \pm 2.1$ & 9.7 & $1.8-2.8$ & $2.3_{c} \pm 0.4$ & 17.4 & 4.9 \\
\hline & 2002 & $24-30$ & $28.3_{b} \pm 1.9$ & 6.7 & $0.2-0.8$ & $0.5 \pm 0.3$ & 60.0 & 1.4 \\
\hline & 2005 & $21-31$ & $25.7_{a} \pm 3.2$ & 12.4 & $1.9-3.5$ & $2.8_{c} \pm 0.7$ & 25.0 & 7.2 \\
\hline & 2008 & $18-44$ & $29.9_{b} \pm 8.0$ & 26.7 & $0.5-2.2$ & $1.4_{a b} \pm 0.7$ & 50.0 & 4.2 \\
\hline & 2012 & $11-27$ & $19.4_{a} \pm 5.2$ & 26.8 & $0.6-1.8$ & $1.3_{b} \pm 0.5$ & 38.5 & 2.5 \\
\hline & Mean & & $25.4_{A} \pm 7.6$ & 29.9 & & $1.6_{A} \pm 0.9$ & 56.2 & 4.0 \\
\hline \multirow{4}{*}{$\begin{array}{l}\text { Potentilla } \\
\text { fruticosa } \\
\text { 'Blink' }\end{array}$} & 2005 & $22-34$ & $27.4_{a} \pm 3.8$ & 13.8 & $0.9-2.7$ & $1.7 \pm 0.8$ & 47.9 & 4.7 \\
\hline & 2008 & $33-42$ & $37.4_{b} \pm 2.4$ & 6.4 & $0.3-1.2$ & $0.7 \pm 0.4$ & 58.8 & 2.6 \\
\hline & 2012 & $24-38$ & $30.2_{a} \pm 3.8$ & 12.5 & $0.5-2.2$ & $1.5 \pm 0.7$ & 46.6 & 4.5 \\
\hline & Mean & & $31.1_{\mathrm{B}} \pm 4.8$ & 15.4 & & $1.3_{\triangle} \pm 0.7$ & 53.8 & 3.9 \\
\hline
\end{tabular}




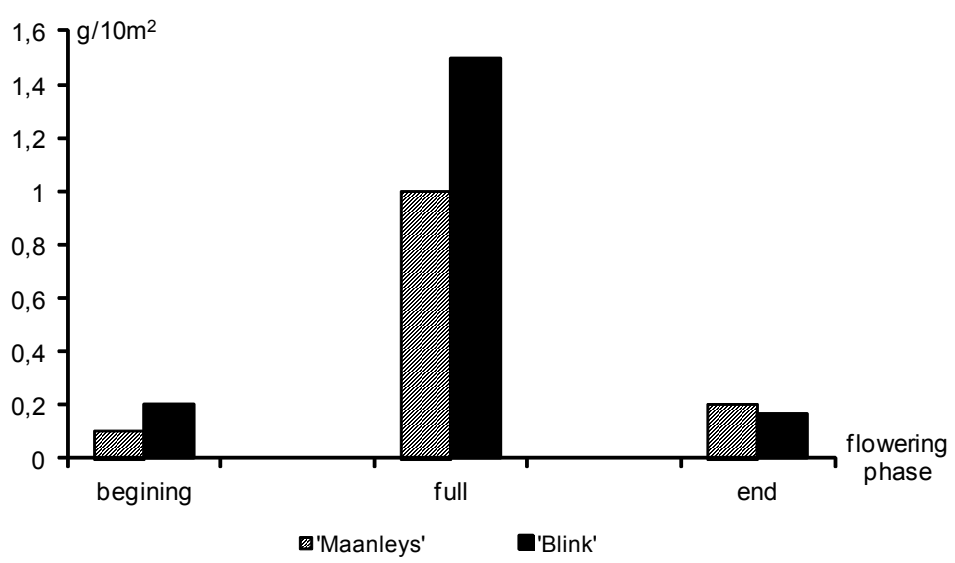

Fig. 4. The mass of pollen delivered in succesive stages of blooming per $10 \mathrm{~m}^{2}$ crown of two cultivars of Potentilla fruticosa studied in Lublin, SE Poland.

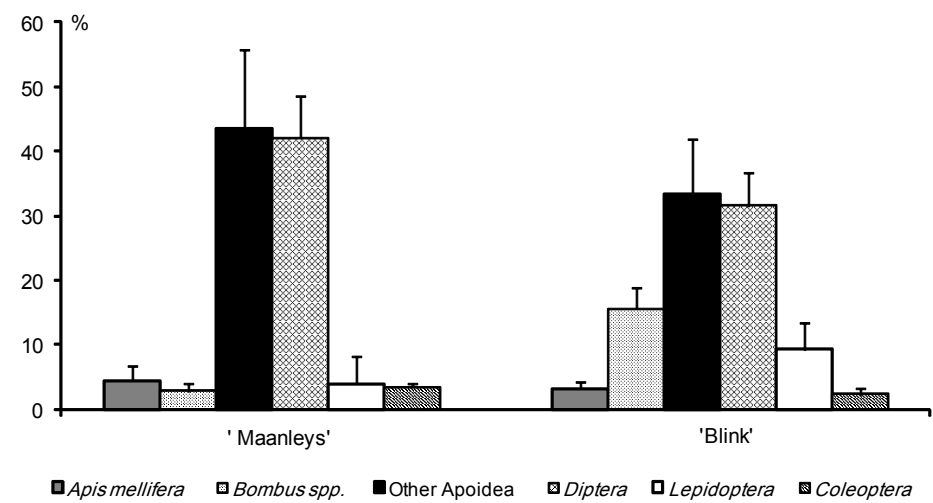

Fig. 5. The participation of insect visitors on flowers of two cultivars of Potentilla fruticosa studied in Lublin, SE Poland. Mean from years 2008 and 2012. Vertical bars indicate SD.

Participation of insect groups foraging on studied cultivars and activity pattern

Potentilla fruticosa flowers attract different insect visitors (Figs. 5, 6). Nocturnal observations excluded insect visits after dusk. Under favorable weather conditions, insects started to visit flowers in the early morning hours. The highest number of insects was present between 11.00 and 15.00. The Dipterans and Bombus spp. were the first to start visiting at around $7.00-8.00$. The activity pattern of flies picked up in the morning and in the early afternoon. The highest number of bumblebees were recorded at 8.00 and 19.00. Apis mellifera was active from 8.00 with three peak periods. The activity pattern of lepidopterans picked up between 12.00 and 16.00. Apis mellifera and Bombus spp. collected light brown pollen loads. Solitary bees and dipterans predominated among the insect visitors of both the studied cultivars. Bumblebee and butterfly participation varied between cultivars. Apis mellifera showed little interest in foraging on flowers of both cultivars of $P$. fruticosa. The diurnal pattern of insect visitors was similar for both cultivars studied, therefore, data are presented as averages (Fig. 6). Bumblebee visits to Potentilla fruticosa flowers were very irregular. The most stable activity was characteristic for dipterans. Lepidopterans usually foraged flowers during the midday hours. 


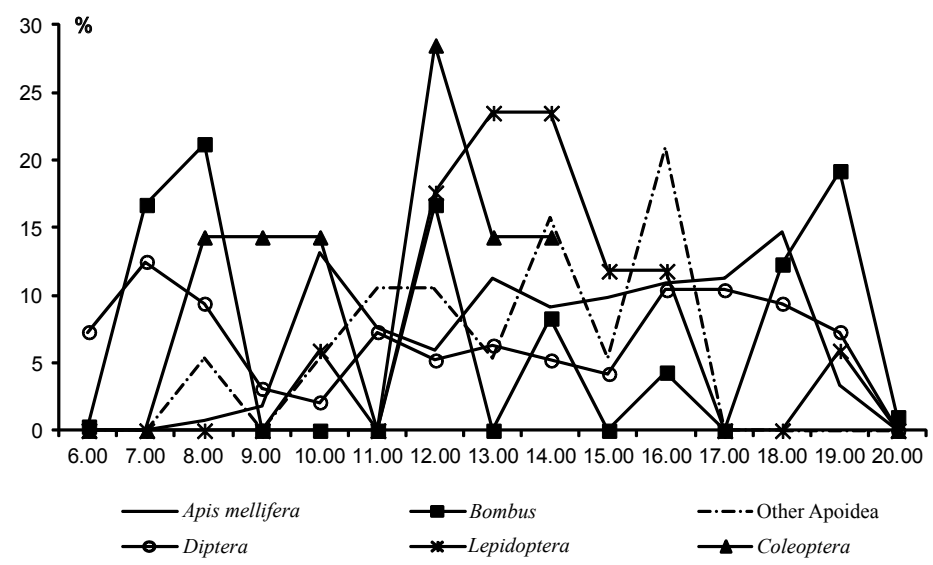

Fig. 6. The pattern of diurnal insect visitors activity as proportion in 1-hour intervals on Potentilla fruticosa (averages for 'Maanleys' and 'Blink') studied during June and August in Lublin, SE Poland. Means from 2008 and 2012.

\section{DISCUSSION}

In the environmental conditions of central Europe, Potentilla fruticosa ('Maanleys' and 'Blink') bloom from May until the end of September or even October (Bugała, 2000; Vliet et al., 2003), and the flowering in SE Poland is no exception.

The diurnal pattern of blooming differed slightly for both cultivars. The feature is highly species specific and also differs among cultivars (van Doorn and van Meeteren, 2003; Denisow, 2009). Moreover, the diurnal dynamics of flower opening changed only a little during a growing season. Generally, Potentilla fruticosa flowers opened earlier in the early summer period compared to the late summer period. A tendency towards a shift in the daily rate of the opening of new flowers for those species which have a long blooming period was documented earlier (e.g Taraxacum officinale, Lamium album, or Berteroa incana) (Denisow, 2009). The phenomenon can be associated with decreasing day length and with the reaction to abiotic factors (temperature and humidity) at the moment of anthesis (van Dorn and van Meeteren, 2003). Furthermore, such a strategy allows to attract pollinators and adopt the plant to the changeable seasonal activity of pollinators
(Goulson, 1999; Wróblewska and Stawiarz, 2012). The synchronization of plant-insect visitors is crucial for the effective reproduction of entomophilous plants. The interaction depends on the relative attractiveness of a floral display to pollinators. The floral display function is mainly a visual attractant of a secondary type. During the initial flowering phase, the flower density of the studied cultivars of $P$. fruticosa, was only approx. $21-64$ flowers per $1 \mathrm{~m}^{2}$ of shrub crown, and approx. 253 - 768 flowers per $1 \mathrm{~m}^{2}$ of shrub crown in the full blooming stage. Plant species have different floral display strategies. Abundant flowering is not widespread among longflowering species as individuals spend most of their energy on flower production (Robertson and Macnair, 1995). Additionally, the flower life-span was long; c.a. 4 - 11 days. According to van Overbeke et al. (2007) the longevity of an individual flower of $P$. fruticosa observed in a natural community, was 4 - 8 days - but the study concerned shrubs grown at high altitudes in the mountains. As highlighted by different authors, habitat and environmental conditions (temperature, humidity) are essential for the flower lifespan (van Dorn and van Meeteren, 2003). Moreover, the 'Maanleys' and 'Blink' cultivars involved in our study, 
are ornamentals. Most likely, they were selected for a life-span elongation. Prolonged flower life-span appears to be of great value to pollinators as it extends the food supply.

During our observations, pollen was the only flower reward available for pollinators in the flowers of the studied cultivars. Nectar secretion was reported in flowers of Potentilla fruticosa by van Overbeke et al. (2007). Although the quantity was very low, the authors documented the use of flowers as a nectar source for lepidopterans, in the late summer and during periods of drought when the availability of nectariferous plants was reduced. In our study, butterflies on flowers (mainly on 'Blink'- $14 \%$ of total visitors) were also observed but we did not find any nectar secretion. We applied the standard pipette method which might have been inadequate for such small nectar amounts. The quantity reported for Potentilla fruticosa is minute ( $<1 \mathrm{ml}$ per flower) (van Overbeke et al., 2007). However, the base of the ovary of $P$. fruticosa 'Maanleys' and 'Blink' is covered with numerous hairs, slightly inflated with air, that efficiently reflect sunlight, mimic the presence of nectar, and may attract butterflies. The other possible factor that attracted lepidopterans to 'Blink' flowers was the pink color of corolla. The bright colours (e.g. violet and pink) are known to be favorable by different types of butterflies (Faegri and van der Pijl, 1979).

The pollen presentation in multistaminate flowers of both cultivars of P. fruticosa started 2 - 3 hours after corolla opening. The phenomenon of anther dehiscence in 1 - 3 hours after anthesis begin is common among different species (Szklanowska, 1978; Szklanowska and Strzałkowska, 2001). In Spain, Guillen et al. (2005) observed a slightly different anther opening, immediately after the anthesis initiation, for varied Potentilla. The thecae splitting is known to be highly temperature dependent (Keijzer, 1987; Bożek, 2003). The higher Mediterranean climate temperatures presumably affected the rapid anther dehiscence.

A significant year effect on the number of anthers developed per flower was noted. This indicates the influence of weather factors on the androecium formation, and is in accordance with observations concerning other multi-staminate flowers (e.g. Szklanowska, 1978; Denisow, 2011).

In this study, lack of rainfall and air temperatures that exceeded the norm in the time before flowering and during blooming phases, had an impact on the mass of pollen produced in anthers. An extremely low pollen mass was noted for 'Maanleys' in 2002 with the substantial rainfall deficit, when compared to long term data. Fluctuations in humidity and temperature are considered as limiting factors for plant growth and are also substantial for reproduction (Pacini et al., 1997). According to Hedhly et al. (2008), production of plant pollen is known to be most sensitive to high temperature stress. Lack of precipitation was documented as a cause of decline in the pollen mass of entomophilous ruderal taxa (Denisow, 2009; 2011) or even Mediterranean species with better tolerance and adaptations to higher temperatures (Bożek, 2003).

Szklanowska (1983) established the mass of pollen produced in Rosaceae flowers and underlined substantial disparities from $2.5 \mathrm{mg}$ to $15.6 \mathrm{mg}$ per 10 flowers. Also in P. fruticosa flowers, due to multi-anthers androecium, differences in the mass of pollen produced in flowers were observed.

The estimated pollen output, from $1.0 \mathrm{~g}$ to $1.5 \mathrm{~g}$ per $10 \mathrm{~m}^{2}$, indicates that investigated cultivars of Potentilla fruticosa may be treated as pollen yielding plants, but the values obtained are lower than those established for Rosaceae shrubs (e.g. $70 \mathrm{~g} / 10 \mathrm{~m}^{2}$ - Rosa multiflora or Chaenomeles japonica (Szklanowska, 1983; Szklanowska and Strzałkowska, 2001). Due to the flower size (c.a. 2 - $4 \mathrm{~cm}$ in diameter) and the actinomorphic shape, 
the pollen was easily accessible to different groups of pollinators. Despite the fact that the amount of delivered pollen was not exceptionally high, the studied cultivars were attractive to a variety of pollinators and not just Apoidea. The fact underlines the importance of these plants in the maintenance of general insect biodiversity. The common interest in pollen food of ornamental taxa by wild Apoidea was confirmed by Teper (2005).

Shrubs of $P$. fruticosa are very popular in Japan and are gaining popularity in Europe, including Poland. Different cultivars are propagated for use in formal ornamental gardens as well as for very specific arrangements (e.g. bonsai). The rapid development of small urban courtyards creates the possibility of using such areas not only for ornamental purposes but for a food supply for insects. As concluded by Fussell and Corbet (1992), Carreck and Williams (1997), and Goulson et al. (2008), the more diverse the plant arrangement, the more diverse the insect visitors.

\section{REFERENCES}

Aizen M. A., Ashworth L., Galetto L. (2002) - Reproductive success in fragmented habitats: do compatibility systems and pollination specialization matter? J. Veg. Sci., 13: 885-892.

Banaszak J. (1995) - Natural resources of wild bees in Poland and an attempt at estimation of their changes, in: Banaszak J. (Ed.) Changes in Fauna of Wild Bees in Europe. Pedagogical Univ., Bydgoszcz, pp.11-25 ( $1^{\text {st }}$ edition).

Bugała W. (2000) - Drzewa i krzewy. [Trees and shrubs]. PWRiL, Warszawa, pp. 419-420.

Bożek M. (2003) - Kwitnienie, pożytek pyłkowy i owady zapylające kwiaty Hyssopus officinalis L., Lavandula angustifolia Mill. i Mentha piperita L. [Flowering, pollen production and pollinators on Hyssopus officinalis L., Lavandula angustifolia Mill. and Mentha piperita L.]. Annales UMCS s. EEE., 13: 93-99.
Carreck N., Williams I. (1997) Observations on two commercial flower mixtures as food sources for beneficial insects in UK. J. Agri. Sci., 128: 397-403.

Denisow B. (2009) - Factors determining diurnal dynamics of blooming of chosen plants species. Acta Agrobot., 62(1): 83-89.

Denisow B. (2011) - Pollen production of selected ruderal plant species in the Lublin area. Univ. Life Sci. Press, Lublin, 86 pp.

Faegri K., van der Pijl L. (1979) - The principles of pollination ecology. $3^{\text {rd }} \mathrm{rev}$. ed. Pergamon Press, Oxford, 244 pp.

Fussell M., Corbet S. A. (1992) - Flower usage by bumble-bees: a basis for forage plant management. J. Appl. Ecol., 29: 451-465.

Goulson D. (1999) - Foraging strategies of insects for gathering nectar and pollen, and implications for plant ecology and evolution. Perspect. Plant Ecol. Evol. Syst., 2(2): 185-209.

Goulson D., Lye G.C., Darvill B. (2008) - Decline and conservation of bumble bees. Annu. Rev. Entomol., 53: 191-208.

Guillen A., Rico E., Castroviejo S. (2005) - Reproductive biology of the Iberian species of Potentilla L. (Rosaceae). An. Jard. Bot. Madr., 62(1): 9-21.

Hedhly A., Hormaza J. I., Herrero M. (2008) - Global warming and plant sexual reproduction. Trends Plant Sci., 14: 30-36.

Jabłoński B., Szklanowska K. (1997) - Wpływ niektórych czynników pogody na kwitnienie, nektarowanie, pylenie i oblot przez owady zapylające entomofilnych roślin uprawnych. [The influence of some weather factors on blooming, nectar secretion, pollen presentation and insects forages on plants crop]. LTN, Lublin, pp. 53-58.

Jabłoński B. (2002) - Notes on the method to investigate nectar secretion rate in flowers. J. Api. Sci., 46(2): 117-124.

Keijzer C. J. (1987) - The processes of anther dehiscence and pollen dispersal. Part I. The opening mechanism of longitudinally dehiscing anthers. New Phytol., 105: 487-498. 
Kołtowski Z., Jabłoński B. (2001) - Attempt to develop an assortment of herbaceous honey-producing plants to be used for the improvement of bee pastures on idle lands. J. Apic. Sci., 45(1): 21-28.

Kołtowski Z. (2006) - Wielki Atlas Roślin Miododajnych. [Great Atlas of Melliferous Plants]. Wyd. Rzeczpospolita, Warszawa. (in Polish), 327 pp.

Lipiński M. (2010) - Pożytki pszczele. Zapylanie i miododajność roślin. [Melliferous flora. Pollination and plants melliferous value]. IV ed., PWRiL, Warszawa, (in Polish), 320 pp.

Masierowska M. (2012) - Floral phenology, floral rewards and insect visitation in an ornamental species Geranium platypetalum Fisch. \& C. A. Mey., Geraniaceae. Acta Agrobot., 65(2): 23-36.

Pacini E., Franchi G., Lisci M., Nepi M. (1997) - Pollen viability related to type of pollination in six Angiosperm species. Ann. Bot., 80(1): 83-87.

Robertson A. W., Macnair M. (1995) The effect of floral display size on pollinator service to individual flowers of Myosotis and Mimulus. Oikos, 72: 106-114.

Stanisz A. (1996) - Przystępny kurs statystyki $\mathrm{Z}$ zastosowaniem Statistica na przykładach $\mathrm{z}$ medycyny. [Accessible course in statistics using Statistica Software on examples from medicine]. Statsoft Polska, Kraków, 359 pp.

Szklanowska K. (1978) - Nectar secretion and productiveness of some trees and bushes in Poland. Pszczeln. Zesz. Nauk., 22: 117-128. (in Polish).

Szklanowska K. (1983) - Pollen production of tree and bush fruit. In Proceedings of $V$ Symposium International sur la Polllination. Versailles, 27-30 September, pp. 17-18.
Szklanowska K. (1995) - The pollen flows of crowfoot family (Ranunculaceae L.) from natural plants communities, in: Banaszak J. (Ed.). Changes in Fauna of Wild Bees in Europe. Pedagogical Univ. Bydgoszcz, pp. 201-214.

Szklanowska K., Strzałkowska M. (2001) - Blooming biology and food value of shrubs Rosa multiflora Thunb. Annales UMCS s. EEE., 9: 33-41.

Teper D. (2005) - Comparison of food plants of Bombus terrestris L. and Bombus lapidarius L. based on pollen analysis of their pollen loads. J. Api. Sci., 49(2): 43-50.

Torchio P. F. (1994) - The present status and future prospects of non-social bees as crop pollinators. Bee World., 75(2): 49-53.

van Doorn W. G., van Meeteren U. (2003) - Flower opening and closure: a review. J. Exp. Bot., 48: 1615-1622.

van Overbeke D. R., Klejnties P. K., Fettig S. M. (2007) - Potentilla fruticosa (Rosaceae) as a nectar plant for butterflies. J. Lepid. Soc., 61(4): 222-227.

Vliet A. J. H., Braun P., Brügger R., Bruns E., Clevers J. (2003) - European phenology network. Nature's calendar on the move. Wageningen Univ. The Netherlands, $64 \mathrm{pp}$.

Williams I. H., Corbet S. A., Osborne J. L. (1991) - Beekeeping, wild bees and pollination in the European Community. Bee World., 72(4): 170-180.

Wróblewska A., Stawiarz E. (2012) Flowering of two Arctium L. species and their significance as a source of pollen for visiting insects. J. Api. Res., 51(1): 78-84. 


\title{
KWITNIENIE, WYDAJNOŚĆ PYŁKOWA \\ ORAZ OBLOT PRZEZ OWADY \\ OZDOBNEGO KRZEWU \\ POTENTILLA FRUTICOSA L. (ROSACEAE)
}

\author{
Denisow B., Antoń S., Szymczak G. \\ S t r e s z c z e n i e
}

Uprawa różnych gatunków entomofilnych roślin ozdobnych w terenach zieleni miejskiej istotnie wpływa na utrzymanie lokalnych populacji owadów zapylających. W niniejszej pracy przedstawiono wyniki wieloletnich badań dotyczących obfitości i dynamiki kwitnienia, wydajności pyłkowej oraz oblotu kwiatów przez owady dwóch ozdobnych odmian Potentilla fruticosa L. ('Maanleys' oraz 'Blink') uprawianych na terenie Lublina. Przeciętnie kwitnienie P. fruticosa 'Maanleys' rozpoczynało się $\mathrm{w}$ połowie maja i trwało do pierwszej dekady września, natomiast termin kwitnienia $P$. fruticosa 'Blink' przypadał w okresie od czerwca do października. Dzienna dynamika rozkwitania była podobna w przypadku obu odmian. W ciagu dnia szczyt rozkwitania obserwowano o godz. $8.00(\mathrm{GMT}+2 \mathrm{~h})$, gdy rozkwitało od 80 - 90\% wszystkich kwiatów, ale wystapiło nieznaczne opóźnienie dziennego rytmu kwitnienia w okresie lato/jesień w stosunku do okresu wiosna/lato. Masa pyłku produkowanego w kwiatach zależała od liczby wykształcanych pręcików oraz efektywności tkanki archesporialnej. Wydajność pyłkowa z 10 kwiatów 'Maanleys' wahała się w granicach 1,4 - 7,2 mg, zaś 10 kwiatów 'Blink' produkowało 2,6 - 4,5 mg pyłku. Średnia wydajność pyłkowa w pełni kwitnienia była stosunkowo niska i wyniosła 1,0 g ('Maanleys') oraz 1,5 g ('Blink') na każde $10 \mathrm{~m}^{2}$ powierzchni krzewów. Kwiaty badanych odmian $P$. fruticosa zwabiały owady, głównie: pszczoły samotnice (33 - 43\%), muchówki (31 - 42\%), motyle (4 - 14\%), trzmiele (3 - 15\%) oraz pszczołę miodną ( 3 - 4\%). Z uwagi na długi okres kwitnienia oraz walory dekoracyjne, krzewy $P$. fruticosa 'Maanleys' oraz 'Blink' mogą być wykorzystywane w założeniach zieleni miejskiej, stanowiąc równocześnie uzupełnienie pokarmu pyłkowego dla owadów.

Słowa kluczowe: dzienna dynamika kwitnienia, wydajność pyłkowa, ochrona zapylaczy, pastwiska dla owadów, Potentilla fruticosa L. 